\title{
MOTIVASI PENGEMBANGAN DAN PEMATANGAN KARIR KEWIRAUSAHAAN DI PONDOK PESANTREN
}

(Kajian di Pondok Pesantren al-Rabbani Cikeas)

\author{
Nani Almuin ${ }^{1}$, Solihatun ${ }^{2}$, Sugeng Haryono ${ }^{3}$ \\ ${ }^{1,2,3}$ Universitas Indraprasta PGRI \\ Email: nanialmuin@yahoo.com
}

\begin{abstract}
Entrepreneurship education not only teaches in a public school science course but this time entrepreneurship has become a trend today that has been widely adopted by educational institutions based schools. Santriwan entrepreneurial learning curriculum and female students form a moderate boarding school, after graduation is not only a tutor but can build an entrepreneurial career as a pious and fair. This study uses descriptive Qualitative analysis based on the analysis of modern pesantren institutions that have been successful in running the entrepreneurship curriculum. Motivation career development and maturation in the boarding school al Rabbani generally can be done, just need to be given the maturity and debriefing basics of entrepreneurship to be more effective. Motivational counseling and debriefing program development and maturation of entrepreneurial career in boarding school Al Robbani aiming to make dropout to be creative, innovative and mature to build a career in the field of entrepreneurship. With the knowledge of entrepreneurship into capital and the best way towards a successful entrepreneur.
\end{abstract}

Keywords: Education, motivation, entrepreneurship, career, management and development

\begin{abstract}
ABSTRAK
Pendidikan kewirausahaan tidak hanya di ajarkan di sekolah umum saja namun saat ini ilmu kewirausahaan sudah menjadi trend masa kini yang sudah banyak diterapkan oleh lembaga pendidikan berbasis pesantren. Kurikulum pembelajaran kewirausahaan membentuk santriwan dan santriwati pondok pesantren yang moderat, setelah lulus tidak hanya menjadi guru mengaji namun bisa membangun karir menjadi seorang wirausaha yang soleh jujur dan adil. Penelitian ini menggunakan metode kualitiatif deskriftif analisis berdasarkan analisis lembaga pesantren modern yang sudah sukses dalam menjalankan kurikulum kewirausahaan. Motivasi pengembangan dan pematangan karir di pondok pesantren al Rabbani umumnya bisa terlaksana, hanya saja perlu diberikan kematangan dan pembekalan dasar-dasar ilmu kewirausahaan agar lebih efektif. Program penyuluhan dan pembekalan Motivasi pengembangan dan pematangan karir kewirausahaan di pondok pesantren Al Robbani bertujuan menjadikan remaja putus sekolah menjadi kreatif, inovatif serta matang membangun karir di bidang wirausaha. Dengan bekal ilmu kewirausahaan menjadi modal dan cara yang terbaik menuju seorang wirausahawan yang sukses.
\end{abstract}

Kata kunci : Pendidikan, Motivasi, Kewirausahaan, karir, pengelolan dan pengembangan, 


\section{PENDAHULUAN}

Pondok Pesantren merupakan salah satu perguruan yang berbasis pendidikan informal karena pondok pesantren menerapkan kurikulum berbasis syariah Islam, seperti ilmu salafi, ilmu al quran, ilmu tarekat, ilmu balaghah, ilmu mantiq dan masih banyak kurikulum pendikan Islam yang diajarkan di setiap pondok pesantren. Abad ke 21 pendidikan di pondok pesantren tidak hanya berbasis informal namun sudah banyak yang berbasis pendidikan formal, hasil pengamatan kementerian pendidikan nasional saat ini metode pendidikan pondok pesantren sudah moderen. Pendidikan di Pondok pesantren saat ini sudah go international, artinya telah mengalami kemajuan dari berbagai sector. Hal ini dilakukan pondok pesantren untuk mempersiapkan para santri agar tidak hanya menguasai keilmuan agama saja tetapi juga ilmuilmu yang sifat umum lainnya. Cita-cita kedepan Indonesia akan menjadi pusat peradaban Islam dunia ini lah yang menjadi tantangan bagaimana pendidikan di pondok pesantren berbasis formal harus di terapkan.

Saat ini pendidikan di pondok pesantren pun sudah banyak yang membentuk kurikulum berbasis enterpreneur, tujuanya agar kelak santri keluar dari sekolah pondok pesantren memiliki pandangan yang matang terkait karir wirausaha, dengan demikian menghilangkan Paradigma terhadap lulusan pesantren yang hanya bisa mengaji dan menjadi ustadz atau ustadzah (sebutan sebagai guru ngaji /guru agama) saja. Pendidikan di pondok pesantren bisa membentuk generasi yang cerdas mandiri dan kreatif melalui bimbingan karir menjadi wirausaha. Berikut beberapa pesantren yang telah sukses yaitu : Pondok pesantren Gontor yang telah berdiri selama 90-an tahun saat ini sudah melahirkan jutaan santri yang produktif tidak hanya dibidang akademisi namun juga dibidang bisnis, hingga akhirnya para alumni-almuni pondok pesantren membentuk forum jaringan pengusaha muslim Indonesia (JPMI). Pesantren Gontor membentuk unit usaha melalui yayasan Kopontren Gontor seperti: penggilingan padi, percetakan Darussalam, KUK Palen, KUK took Besi, Toko Buku, UKK Mini market, Bakso La tansa, KUK foto copi, warteg, apotik, pabrik roti, konveksi, dan masih banyak jenis wirausaha lainnya yang saat ini menjadi unit usaha Pondok pesantren Gontor. (Uswatun Hasanah, 2013). Selain gontor yang sudah maju dan besar, pada tahun 2013 Yayasan Hidayatullah Islamic Center Bekasi
(HICB) yang baru merintis pengelolaan pesantren tahfidz Quran melalui program dakwah ekonomi sosial dan pengembangan SDM. Pondok pesantren ini mengembangkan sayap dengan fokus terhadap tahfidz quran dan wirausaha.

Pondok pesantren modern Darussalam Gontor pondok pesantren yang menerapkan system entrepreneurship bagi para santri dan masyarakat sekitar menjadi salah satu model percontohan yang bisa dijadikan model dan yang bisa diikuti oleh setiap pengelola pondok pesantren dan telah berlangsung kurun waktu yang cukup lama. Tidak hanya Pondok modern Darussalam Gontor yang sudah maju dan besar, pada tahun 2013 Yayasan Hidayatullah Islamic Center Bekasi (HICB) yang baru merintis pengelolaan pesantren tahfidz Quran melalui program dakwah ekonomi sosial dan pengembangan SDM. Pondok pesantren ini mengembangkan sayap dengan fokus terhadap tahfidz quran dan wirausaha.

Dengan demikian Pendidikan keagamaan tidaklah memberi batasan ruang gerak yang sempit bagi setiap santri yang akan hendak berkreatifitas akan tetapi justru memotivasi dan mendorong setiap manusia bisa berubah dan bisa untuk mandiri. Seperti yang diungkapkan oleh Herman Nirwana (Kumpulan Makalah Malindo 2 dan kongres ikatan konselor (IKI divisi ABKIN) "tidak ada suatu masyarakat yang tidak bisa berubah", tiga faktor yang bisa bertumpu terhadap diri seseorang adalah : a) keinginan dan putusan yang sadar untuk mengadakan perubahan; b) sikap probadi yang ingin berubaha karena kondisi social dan c) pribadi atau kelompok yang menonjol dalam masyarakat yang menginginkan perubahan. Pembentukan sumber daya manusia yang berkualitas menjadi tanggung jawab bersama antara keluarga masyarakat, pemerintah.

Pondok pesantren al-Rabbani adalah salah satu lembaga pendidikan yang memberdayakan sistem pendidikan bagi anak remaja yang putus sekolah, salah satu program yang sangat menarik adalah sistem pendidikan yang memotivasi para remaja tersebut untuk terus menggali ilmu pendidikan Agama dengan membaca kitab kuning, Tafsir, Fiqih dan lain sebagainya. Namun ilmu dari sisi pendidikan keagamaan saja tidak bisa membekali mereka dalam menggapai karier untuk itu perlu menerapkan pendidikan enterpreneuship agar tidak hanya paham dari sisi ilmu pendidikan agama tapi mendidik menjadi seorang 
enterpreneur supaya kelak membentuk karir bagi diri mereka setelah lulus dari pesantren. Umumnya membangun kreatifitas dan menumbuhkan jiwa entrepreneurship merupakan cara untuk bisa menjadikan para remaja agar mandiri secara finansial.

Penelitian dan pengkajian motivasi kewirausahaan di pondok pesantren Al Rabbani bertujuan untuk memberikan pelatihan dan pembekalan ilmu kewirausahaan serta bagaimana mengembangkan karir bagi santri remaja yang putus sekolah. Manfaat pelatihan agar supaya santri bisa membentuk kematangan karir ber karakter pribadi yang mandiri, kreatif serta menjadi wirausaha. Lokasi penelitian di Pondok pesantren Al Robbani menjadi salah satu objek pilihan peneliti karena minimnya pendidikan kewirausahaan serta pengembangan karir yang belum begitu matang untuk para santri, meskipun di pondok pesantren ini sudah menyediakan wadah entrepreneurship. Metode penelitian yang digunakan kualitatif deskriptif analitis berdasarkan studi pondok pesantren Ponorogo Darussalam Gontor.

\section{METODE}

Dalam penelitian ini, penulis menggunakan metode pendekatan kualitatif dengan kajian deskriptif-eksplanatif-analitis. Metode ini bermaksud menjelaskan hakekat fakta tertentu, mengapa suatu fakta terjadi dan bagaimana hubungannya dengan fakta yang lain. Data penelitian diperoleh melalui teknik pengumpulan data, baik kepustakaan maupun wawancara terstruktur mengenai masalah-masalah yang berkaitan dengan motivasi dan pengembangan karir kewirausahaan khususnya di pondok pesantren al Rabbani Cikeas.

Data dalam penelitian ini terdiri dari data primer dan data sekunder. Menurut Sugiono (2005:62) Data primer diperoleh secara langsung dari informan melalui wawancara secara mendalam yang dilakukan mengenai pengembangan kewirausahaan di pondok pesantren al Rabbani. Sedangkan data sekunder didapatkan melalui dokumentasi, catatan-catatan peneliti selama penelitian dan pengkajian, serta literatur yang mendukung; baik melalui studi kepustakaan maupun hasil penelitian yang relevan.

Metode dan teknik pengumpulan data: pertama, dengan field research (studi lapangan). Metode ini adalah metode pengumpulan data langsung dari lapangan, atau langsung dari sumber data (responden), pengumpulan data dengan metode dilakukan dengan menggunakan teknik-teknik pengumpulan data, antara lain: 1) teknik wawancara. (Koentjaraningrat, tt (cet. XIV: 129) Wawancara pada dasarnya merupakan langkah pencarian atau pengumpulan data dengan melakukan tanya-jawab secara langsung pada obyek/responden yaitu : Pengurus Yayasan pondok pesantren Al Rabbani, dan santri pondok pesantren Al rabbani, yang dilaksanakan secara sistematis dan berlandaskan pada tujuan penelitian; 2) teknik observasi (pengamatan). Observasi adalah teknik pengumpulan data dengan mengadakan pengamatan secara langsung dan mencatat berkas-berkas,kejadian-kejadian terkait fenomena pondok pesantren dalam membangun kewirausahaan di pondok pesantren. Observasi, di samping sebagai teknik pengumpulan data pada studi lapangan, juga bisa berperan sebagai metode tersendiri, namun fungsi dan perannya adalah sebagai bentuk pengamatan dari seorang peneliti.

Kedua, studi kepustakaan/dokumentasi. (Sugiono, 2008 : 308), Metode ini merupakan metode pengumpulan data melalui kajian terdahulu, berdasarkan dokumen-dokumen, teoriteori, dan konsep-konsep yang berkaitan dengan karir dan kewirausahaan. Data yang diperoleh dari beberapa sumber selanjutnya dianalisis secara kualitatif deskriptif analisis.

\section{HASIL DAN PEMBAHASAN}

Peran kewirausahaan umumnya sudah banyak di ajarkan di setiap lingkungan pondok pesantren, dan sudah memiliki model serta system yang berbeda-beda. pondok pesantren yang sudah ternama dan teruji adalah memberdayakan SDM santri dibidang entrepreneur adalah pondok pesantren Moderen Darussalam Gontor.

Pondok modern Darussalam gontor jika ditelusuri sejarahnya berasal dari pesantren tradisional Tegalsari. Pondok pesantren Gontor dengan penerapan system pendidikan moderen berkembang pesat terlebih lagi setelah pemimpin pondok mengambil langkah strategic dengan melakukan modernitas tidak terbatas pada system penyelenggaraan tetapi menyentuh bidang pengelolaan yang tidak terkonsentrasi pada figur kiyai. Pondok pesantren gontor memiliki manajemen yang unik, Trimurti selaku pendiri pondok pesantren Gontor memberikan otoritas kepada sebuah lembaga lain dalam pengelolaan 
dan pengembangan pesantren. Sejak tahun 1970 pondok pesantren Gontor melalui lembaga wakaf yang ditunjuk oleh pendiri pesantren membangun unit-unit usaha perdagangan dengan membangun pabrik penggilingan padi, kemudian dilanjutkan dengan membangun usaha percetakan, emmbangun toko klontongan, toko material, toko buku dan warung-warung santri sehingga di tahun yang sama jumlah unit usaha pondok pesantren gontor mencapai 50 unit lebih. (Rozalinda , 2014: 405)

Pembangunan unit-unit usaha sekedar memenuhi kebutuhan manajemen pondok. Pabrik padi, percetakan, toko klontongan material, toko buku dan warung-warung dibangun untuk mewujudkan kemandirian pondok. Pondok membutuhkan jumlah produksi yang lebih besar dan hasil panen setiap tahun selalu meningkat sehingga di pandang perlu untuk emmbuat penggilingan padi. Demikian pula dengan kebutuhan santri akan buku waji dan buku anjuran pegangan guru setiap jumlahnya mencapai puluhan ribu eksamplar sehingga terpikir untuk memiliki mesin cetak sendiri, faktanya dari hasil unit-unit usaha dimaksud setiap tahun memperoleh keuntungan bersih 5 sampai 7 milyar rupiah dan akhir tahun 2009 naik 15 Milyar. (Rozalinda, 2014:407). Unit usaha yang dikembangkan oleh kopontren terlihat masih terkonsentrasi pada komoditas dan jasa pelayanan yang menjadi kebutuhan santri, belum berorientasi pada pangsa pasar yang lebih luas, namun dengan pendirian unit usaha seperti laundry, pangkas rambut, tukang jahit, warung bakso dikembangkan untuk melatih kemandirian santri dan pengembangan kreatifitas santri.

Manajemen pemberdayaan pondok pesantren gontor ditempuh melalui pemberdayaan sumber daya manusia (SDM) melalui pendidikan dan latihan; pemberdayaan melalui unit-unit usaha terkordinasi dalam koperasi atau dikenal dengan (Kopontren). Pemberdayaan SDM dilaksanakan melalui pusat latihan manajemen pondok pesantren Moderen untuk memberdayakan santri dan masyarakat dalam bidang kewirausahaan. Setiap santri yang akan diterjunkan ke masyarakat dididik dan dilatih dilembaga ini agar memiliki keterampilan yang memadai baik menjadi pemimpin di masyarakat maupun juru dakwah (guru ngaji) yang tidak menggantungkan hidupnya kepada masyarakat.

Jika pesantren gontor bisa sukses terhadap pengembangan lembaga pada unit bisnis yang telah dikembangkan, maka pondok pesantren al Rabbani memiliki peluang dan rencana bisnis untuk mengembangkan dan mematangkan karir bagi remaja putus sekolah di pondok pesantren al Rabbani dengan motivasi membangun dan mematangkan karir kewirausahaan bagi remaja santri pondok pesantren $\mathrm{Al}$ rabbani.

\section{Perkembangan dan Pengelolaan Pondok pesantren al Rabbani}

Tidak terlalu banyak yang bisa di ceritakan dari profil pondok pesantren Al Rabbani, namun di tulisan ini penulis mencoba menjelaskan sekilas tentang sejarah visi misi dan program di pondok pesantren al Rabbani. Yayasan Ma'arif al rabbani berdiri pada tahun 2010 beralamat di jalan Transyogie Cikeas, kp. Nagrak RT 02/03 No. 99 Gunung putri Bogor. Yayasan al Robbani mendirikan wadah lembaga dengan nama al Rabbani Islamic College. Lembaga ini memiliki komitmen bergerak pada bidang pendidikan Islam, pengkajian dan penelitian Islam, enterpreneurship, dakwah dan social. Visi dan misi pondok pesntren al-Rabbani sebagai wadah perjuangan menegakkan kalimat Allah (li-i'lai kalimatillâh) berpegang pada nilai-nilai Islam rahmatan li-l'âlamîn yang menjadi prinsip dalam memperdayakan masyarakat Madani (civil society) dalam membangun bangsa. Misi menyiapkan generasi berkualitas yang dapat berperan aktif dalam membangun bangsa dan Negara, membangun sistem pendidikan yang berorientasi pada aktualisasi nilai-nilai Islam sehingga terbentuk generasi yang memiliki pribadi berakhlakul karimah dan berwawasan Islam ke Indonesiaan Global. Yayasan al Robbani tidak kalah menariknya selalu menyelenggarakan pelatihan berbasis life skill dan entrepreneur untuk membina remaja dan anak putus sekolah dan para santri dengan tujuan kelak mereka akan menjadi generasi kreatif, mandiri dan kompetitif, serta menyelanggarakn pendidikan yang memiliki komitmen social dan pemberdayaan masyarakat sipil (civil society)

Sejak awal pendirian lembaga al Rabbani telah memiliki program pendidikan kagamaan dan sosial program pendidikan, program tersebut terbagi menjadi empat bagian yaitu : Islamic studies and research; Islamic education; entrepreneurship; dan social care. (Ali M. Abdillah, 2013)

\section{Islamic Studies and Research}

Kegiatan Islamic Studies and Research yaitu mengkaji dan meneliti kajian Islam Interdisipliner meliputi kajian al-Qur'an Hadits, Tafsir, Fiqih, Tasawuf, Ilmu Kalam dan Filsafat Islam. Kegiatan pengkajian yang sudah berjalan 
yaitu mengkaji kitab Riyadhu s-shalihin, Tafsir al-Jilani dan kitab lainnya. Dalam bidang penelitian akan meneliti masalah-masalah sosial, budaya dan keagamamaan. Termasuk meneliti manuskrip tasawuf Nusantara yang menjadi salah satu khazanah intelektual Nusantara. Penelitian yang sudah dilakukan yaitu meneliti manuskrip tasawuf para ulama Nusantara.

\section{Islamic Education}

Bergerak dibidang pendidikan formal dan informal, Pendidikan formal yang sudah berjalan dari tahun 2006 yaitu TK. Islam RA. Al-Kamil di Kelapa Dua Wetan, Ciracas, Jakarta Timur. RA Al-Kamil memiliki motto mencetak generasi berprestasi dan berakhlakul karimah. Kepercayaan masyarakat semakin tumbuh saat RA Al-Kamil menunjukkan hasil nyata terhadap perubahan prestasi dan akhlak putra-putri mereka. Para pengajar RA Al-Kamil yang berlatar belakang S1 memiliki prestasi yang membanggakan yaitu Juara 1 dan 2 dalam kreatifitas guru RA se-Jakarta Timur dan DKI Jakarta. Komitmen lembaga dalam membangun pendidikan yang berorientasi sosial telah terbukti secara nyata dengan memberikan program beasiswa gratis biaya untuk anak yatim dan anak tidak mampu.

Program ini berjalan secara rutin tiap tahun. Rencana pengembangan akan mendirikan Sekolah Islam dari TK Islam/RA, SMP, SMU hingga Perguruan Tinggi dalam satu lokasi yang terintegrasi dengan Pondok Pesantren. Sehingga keseimbangan antara pendidikan Agama, pengetahuan umum dan akhlakul karimah dapat terwujud secara nyata.

\section{Pendidikan Informal}

Pendidikan informal yang sudah berjalan yaitu Taman Pendidikan al-Qur'an di Cikeas, Kp. Nagrak, Gunung Putri, Bogor. Pendidikan ini gratis untuk anak-anak masyarakat sekitar Cikeas dan Nagrak. Masyarakat di sekitar lembaga kami merasa senang dengan diselenggarakannya Pengajian Al-Qur'an untuk anak-anak mereka.

\section{Entrepreneurship}

Program ini akan memberikan pembinaan leadership, keagamaan, life skill dan entrepreur kepada para remaja, anak putus sekolah dan santri salafiyah. Tujuannya supaya mereka memiliki bekal kepemimpinan, keahlian dan wirausaha sehingga mereka diharapkan mampu mengembangkan potensi diri secara postif. Pelatihan leadership, life skill dan entrepreneur menjadi program prioritas untuk membekali dan menyiapkan generasi Islam yang berkualitas, bertaqwa, berakhlakul karimah, kreatif dan mandiri. Selain itu, akan dikembangkan pelatihan life skill seperti kursus teknisi komputer, programer, laboratorium Bahasa, percetakan, menjahit, perpustakaan, taman baca, wirausaha dan lainnya.

\section{Social care}

Program pemotongan hewan qurban dan pembagian bingkisan lebaran untuk masyarakat sekitar. Beberapa program kegiatan yang tersebut diatas, masih banyak lagi kegiatan lagi yang tidak bisa dijelaskan semua dalam tulisan ini seperti pengajian mingguan untuk remaja dengan mengkaji kitab riyadhus sholihin, tafsir jailani, nahwu shorof, dan kajian fiqih empat mazdhab. Pada umunya pondok pesantren al Robbani membuka peluang belajar informal untuk membekali para remaja putus sekolah dengan mempelajari ilmu keagamaan tidak lain adalah untuk membekali dan menjadi benteng pertahanan keimanan dan ketakwaan spiritual agar selalu berada di jalan kebenaran. Wallahua'lam. Disamping itu pula menerapkan program entrepreneurship untuk membangun kreatifitas dan kemandirian bagi santri pondok pesantren al Robbani.

\section{Program Kewirausahaan Pondok Pesantren al Rabbani}

Kondisi riil di Indonesia saat ini masih memprihatinkan, pengangguran dikalangan pemuda dan remaja masih merajalela. Susahnya lapangan pekerjaan menjadi dilema dan terpuruknya status sosial bagi mereka yang harus selalu siap dan mendapat perlakuan kurang baik di masyarakat dicap sebagai remaja atau pemuda pengangguran yang hanya bisa berbuat ulah dan onar saja. Jangan kan pemuda yang putus sekolah yang sudah memegang ijazah S1 sebagai sarjana pun terkadang sulit mendapatkan pekerjaan hal ini disebabkan oleh faktor terbatasnya lowongan pekerjaan. Penting kiranya dengan kondisi yang seperti ini menuntut kepedulian pemerintah atau pihak terkait yang bisa peduli untuk memberikan solusi nyata menggadapi pengangguran di Indonesia.

Data ketenagakerjaan Indonesia, jumlah pengangguran meningkat sekitar 10 ribu orang. Yakni, dari 7,02 juta orang pada Februari 2016 menjadi 7,03 juta orang. Memasuki musim panen menyerap tenaga kerja cukup banyak, jika musim 
panen sudah berlalu, dari jumlah penduduk yang bekerja meningkat 3,59 juta orang dari semula 114,84 juta orang pada Agustus 2015 menjadi 118,41 juta orang.(http://www.cnnindonesia.com: di update 7 April 2017)

Pondok pesantren al Rabbani membuka pintu harapan dan memberikan solusi bagi para remaja putus sekolah melalui program entrepreneur al Rabbani. Program enterpreneur al Rabbani bertujuan merubah paradigma dan mind set pemuda remaja yang putus sekolah bahwa tidaklah ada kata terlambat dalam hidup ini jika ingin mencapai rizki dan kesuksesan. Sukses tidak harus menjadi karir sebagai pegawai negeri ataupun karyawan, ketika pintu sudah pada tertutup maka ada pintu lain yang siap untuk dibuka yaitu melalui wirausaha dan yang sangta dibuuthkan adalah knowledge, skill dan attitude (KSA) (Modul kewirausahaan Unindra:2012)

Kegiatan kewirausahaan di pondok pesantren al Rabbani adalah memberikan semacam pembinaan secara teoritis dan praktisi berikut beberapa langkah yang telah diterapkan diantaranya :

Pertama, pembinaan teoritis, kegiatan ini memebrikan pengajaran materi pengenalan diri bagaimana memahami potensi diri sehingga akan muncul kesadaran baru bahwa "tidaklah seseorang akan berubah kecuali dirinya sendiri yang merubahnya". Selanjutnya memberikan pembinaan dalam aspek manajemen bisnis, manajemen keuangan, hal ini diharapkan kelak mereka akan memahami tanpa ilmu manajemen maka akan sulit mencapai kesuksesan. Kedua, menyediakan adisor atau mentor sebagai tutorial hal ini dianggap penting jika mengalami permasalahan rumit maka dengan adanya advisor menjadi alternatif tempat untuk sharing, mengeluh dan mengadu. Ketiga, membangun semangat dan jiwa entrepreneur terhadap remaja putus sekolah dengan melakukan training dan mendatangkan tutorial dari luar untuk memberikan materi-materi kewirausahaan.

Tidak hanya memberikan metode pembelajaran kewirausahaan saja namun pondok pesantren al Rabbani telah melakukan upaya internal dengan bekerjasama kepada stakeholder dalam hal ini lembaga-lembaga social charity seperti Baznas (badan amil zakat); kementerian koperasi dan UKM.
Berdasarkan penjelasan diatas, program kegiatan penerapan kewirausahaan dalam bentuk praktik di pondok pesantren al Rabbani belum menujukkan hasil yang signifikansi meskipun sudah ada contoh penerapan bisnis usaha budidaya ternak lele. Berdasarkan observasi dan studi maka tim Universitas Indraprasta datang mengunjungi dan memberikan penyuluhan bagaimana membangun jiwa entrepreneur dan karir menjadi seorang wirausaha khususnya bagi pemuda remaja putus sekolah di pondok pesantren al Rabbani Cikeas, sosialisasi dan penyuluhan ini sekaligus memberikan praktek kewirausahaan dengan membuat sebuat produk sederhana namun bisa mendatangkan keuntungan.

\section{Motivasi Pengembangan dan Pematangan \\ Karir Kewirausahaan di Pondok Pesantren al Rabbani \\ a. Motivasi kewirausahaan}

Seorang wirausaha tidak hanya menggeluti usahanya sekedar alakadarnya saja akan tetepi dengan kegigihan dan keberanian sehingga usahanya bisa tumbuh secara efektif. Membangun wirausaha menempatkan diri dengan bersahabat bersama ketidakpastian, maka tidak salah setiap siswa mahasiswa yang lulus dari perguruan atau sekolah tempat dia menuntut ilmu berharap ingin mencari pekerjaan dan menjadi karyawan saja karena lebih pasti akan mendapatkan pendapatan setiap bulannya. Menurut Thomas W. Zimmerer, Wirausaha adalah kemampuan yang dimiliki oleh seseorang untuk melihat dan menilai kesempatan-kesempatan bisnis; mengumpulkan sumber daya yang dibutuhkan untuk mengambil tindakan yang tepat dan mengambil keuntungan dalam rangka meraih sukses. (Thomas W. Zimmerer : 1996). Wirausaha adalah kemampuan yang dimiliki oleh seorang untuk melihat dan menilai kesempatan-kesempatan bisnis, mengumpulkan sumber daya yang dibutuhkan untuk mengambil tindakan yang tepat dan mengambil keuntungan dalam rangka meraih kesuksesan. Kewirausahaan pada hakekatnya sifat ciri dan watak seseorang yang memiliki kemauan dalam mewujudkan gagasan inovatif ke dalam dunia nyata. Intinya, seorang Wirausahawan adalah orang-orang yang memiliki jiwa Wirausaha dan mengaplikasikan hakekat Kewirausahaan dalam hidupnya. 
Hakikat kewirausahaan merujuk pada sifat, watak, dan ciri-ciri yang melekat pada seseorang yang mempunyai kemauan keras untuk mewujudkan gagasan inovatif ke dalam dunia usaha yang nyata dan dapat mengembangkannya dengan tangguh. Motivasi kewirausahaan bagi santri pondok pesantren al Rabbani adalah Proses penerapan kreatifitas dan inovasi dalam memcahkan permasalahan dan menemukan peluang untuk memperbaiki kehidupan melalui wirausaha.

Secara umum motivasi seseorang untuk menjadi wirausaha antara lain:

a) Laba; dapat menentukan berapa keuntungan yang dikehendaki, dan berapa yang akan dibayarkan kepada pihak lain atau pegawainya

b) Kebebasan; bebas mengatur waktu, bebas dari supervise, bebas aturan main yang menekan atau intervensi orang lain, bebas dari aturan budaya organisasi atau perusahaan

c) Impian personal; bebas mencapai standar hidup yang diharapkan, lepas dari rutinitas kerja yang membosankan karena harus mengikuti visi, misi dan impian orang lain. Dapat menetukan sendiri visi dan misinya.

d) Kemandirian; bisa bangga karena dapat mandiri dalam segala hal, modal, manajemen, serta menjadi manajer terhadap dirinya sendiri. (Leonardus Saiman: 2009)

Sejak berdirinya pondok pesantren al Rabbani pada tahun 2010 lembaga ini sudah berkomitmen bergerak di bidang pendidikan Islam, pengkajian dan penelitian Islam, dakwah sosial Islam, dan entrepreneurship. Melalui kegiatan pelatihan dan pematangan karir kewirausahaan bagi remaja putus sekolah pondok pesantren al Rabbani bisa membangun motivasi mengembangkan karir menjadi entrepreneurship.

\section{b. Praktek Kewirausahaan di Pondok Pesantren Al Rabbani}

Pondok pesantren al Rabbani adalah salah satu lembaga pendidikan yang memberdayakan sistem pendidikan bagi anak remaja yang putus sekolah, salah satu program yang sangat menarik adalah sistem pendidikan yang memotivasi para remaja tersebut untuk terus menggali ilmu pendidikan agama berupa kitab kuning, tafsir, Fiqih dan lain sebagainya. ilmu dari sisi pendidikan agama saja tidaklah cukup untuk membekali mereka dalam menggapai karir untuk itu maka perlu menerapkan pendidikan entrepreneurship agar siswa tidak hanya memehami ilmu keagamaan saja akan tetepi bisa menjadi seorang entrepreneur agar terbentuk karir bagi diri mereka. Melalui metode membangun kreatifitas dan menumbuhkan jiwa entrepreneur merupakan cara untuk bisa menjadikan para remaja agar mandiri secara financial.

Program entrepreneurship di pondok pesantren al Rabbani bertujuan untuk membangun kreatifitas dan kemandirian bagi para santri. Saat ini program wirausaha yang sudah dijalankan di lingkungan pondok pesantren al Rabbani adalah adalah budidaya ikan lele. program entrepreneur budidaya ikan lele santri al-Rabbani Cikeas berjalan dg baik. Pedoman yang dipegang bagi para santri pondok pesantren al Rabbani adalah sebuah mahfudzot (istilah pribahasa) man yazra' yahsud artinya barang siapa yang menanam maka ia akan panen. Pada akhirnya kalimat singkat ini menjadi motivasi para santri untuk menjadi pribadi yg mandiri.

Program pemberdayaan kewirausahaan melalui budidaya ikan lele adalah program perdana yang dilakukan oleh oleh pesantren al Robbani. Program budidaya ikan lele berorientasi pada pemenuhan kebutuhan pondok untuk membangun dan memfasilitasi kebutuhan para santri, disamping itu juga melatih keterampilan dan kedisplinan para santri remaja di pondok pesantren al Rabbani.

c. Pematangan dan Pengembangan Karir Bagi Remaja Putus Sekolah di Pondok Pesantren al Rabbani

Bekerja bagi setiap manusia adalah dorongan individual dengan motivasi ingin memperbaiki diri, status sosial bahkan bisa meningkatkan finansial. Setiap individu memiliki pilihan, adanya minat dalam diri individu akan menyebabkan individu tersebut berhubungan dengan secara aktif dengan objek yang diminati semakin lama maka akan semakin menyatu dalam hidupnya. Heru Sriyono (2013:18) dalam bukunya menjelaskan "anak-anak dan remaja mengalami kebingungan dan kesulitan dalam memahami, merencanakan dan mempersiapkan diri memasuki dunia kerja. Untuk mengahadapi dan mengatasi masalah dan kebingungankebingungan tersebut, mereka perlu mendapat bantuan dari orang tua, sekolah dan lembaga terkait di sekolah secara umum antara lain pimpinan sekolah, guru-guru dan para pelaksana pendidikan lainnya, melalui pembinaan kesiswaan, proses pembelajaran serta layanan- 
layanan kependidikan lainnya. Layanan yang lebih terencana, sistematis dan terfokus diberikan oleh para konselor pendidikan melalui layanan bimbingan dan konseling, khususnya bimbingan dan konseling karir."

Menurut pendapat Soeradji orang yang bekerja tidaklah terlepas dengan istilah karir, (Soeradji : materi perkuliahan. tt) karir adalah suatu usaha layanan bimbingan yang ditujukan baik secara individual maupun secara kelompok yang sedang berusaha untuk meningkatkan taraf hidupnya ataupun keahliannya dalam lapangan kerja tertentu. bimbingan karir adalah bimbingan dalam mempersiapkan diri menghadapi dunia kerja, dalam memilih lapangan kerja atau jabatan/ profesi tertentu serta membekali diri supaya siap memangku jabatan itu, dan dalam menyesuaikan diri dengan berbagai tuntutan dari lapangan pekerjaan yang dimasuki

Tujuan pengembangan karir secara umum adalah untuk membantu siswa dalam pemahaman dirinya dan lingkungan dalam pengambilan keputusan, perencanaan dan pengarahan kegiatan-kegiatan menuju karir dan cara hidupnya yang akan memberikan rasa kepuasan karena sesuai, selera dan seimbang dengan dirinya serta dirinya dan lingkungannya. (T. Sunarto, tt: 12). Pengembangan karir pada sebuah lembaga pendidikan meliputi beberapa aspek diantaranya : a) pemahaman terhadap dunia kerja; b) perencanaan dan pemilihan karir atau jabatan tertentu; c) penyediaan berbagai program studi yang berorientasi karir; d) nilai-nilai kehidupan yang berkenaan dengan karir; e) citacita masa depan; f) harapan keluarga; g) penyesuain diri terhadap tuntutan yang terkandung dalam karir atau jabatan tertentu; $h$ ) bakat khsuus terhadap karir tertentu; i) Kemungkinan pengembangan karir (Tohirin 2007:113).

Melalui bimbingan karir siswa akan diarahkan dalam mengenal diri dan kemampuannya untuk memahami diri dan senantiasa mampu meningkatkan kemampuannya, melatih dalam merencanakan karirnya sehingga dengan demikian siswa menjadi terlatih dan bersikap dewasa dalam berpikir dan merencanakan karirnya. Dengan bimbingan karir diharapkan siswa mampu dalam merencanakan karirnya dan mampu dalam mengambil keputusan yang tepat untuk karirnya sehingga tercipta adanya sikap yang positif terhadap karir yang menjadi pilihannya. Selain sekolah, pihak lain yang tidak kalah pentingnya adalah orang tua, tokoh masyarakat, pengusaha, pejabat pemerintah dan pihak lain yang terkait dengan proses bimbingan karir, khususnya dalam berwirausaha. Upaya meningkatkan persiapan karir sebagai seorang wirausaha yang tepat, harus didasarkan pada keputusan siswa itu sendiri dengan pemahaman secara benar tentang kemampuan dan minat serta pengenalan karir yang ada di masyarakat. Keberhasilan siswa dalam pemilihan karir yang tepat tidaklah semudah yang dibayangkan untuk itu perlu wawasan tentang persiapan karir dengan cara pemberian layanan bimbingan karir kegiatan usaha mandiri, agar remaja putus sekolah yang menjadi siswa pondok pesantren al Rabbani mempunyai pilihan yang tepat untuk kehidupan masa depannya.

Jika pondok pesantren gontor Menerjunkan santri ke unit-unit usaha dalam rangka melaksanakan sebagian program pondok dengan tujuan pertama agar mereka mendapat pengalaman langsung bagaimana mengelola sebuah perusahaan serta menanamkan kemandirian dalam usaha, meningkatkan pendapatan (kesejahteraan), dapat meningkatkan produktifitas kerja karena secara psikologis mereka mempunyai rasa memiliki terhadap unit-unit usaha milik pondok. Hal seperti ini penting kiranya juga di ajarkan dan ditanamkan untuk para santri pondok pesantren al Rabbani. Pondok pesantren Gontor bisa dijadikan model percontohan yang sangat tepat menjadikan charisma kiyai dominan dalam menumbuhkan ethos kerja yang produktif untuk para santri.

\section{d. Pembinaan karir di pondok pesantren al Rabbani}

Menghadapi persaingan yang ketat di dunia kerja maka pondok pesantren al Rabbani melakukan pembekalan kepada para santri remaja putus sekolah dengan memberikan pelatihan kewirausahaan.Melalui sosialisasi kewirausahaan dan pematangan karir diharapkan menjadi manfaat bagi para remaja putus sekolah santri pondok pesantren al Rabbani Cikeas dalam menambah untuk meningkatkan karir menjadi wirausaha. Target kegiatan memberikan motivasi pengembangan dan pematangan karir kewirausahaan pada remaja yang putus sekolah sehingga santri bisa menentukan karir dalam berwirausaha dan dapat menghadapi tantangan hidup dimasyarakat kelak. Beberapa langkah yang dilakukan oleh adalah dengan memberikan 
beberapa keahlian yang bisa di jadikan standar keilmuan bagi santri remaja di pondok pesantren al Rabbani. Pembinaan karir bagi para santri diikuti dengan memberikan beberapa pelatihan keilmuan dasar terkait kewirausahaan seperti:

a. Memberikan materi pembelajaran mengenai kewirausahaan dan pengembangan karir

b. Memberikan penjelasana terkait operasional mengenai bagaimana mencari peluang dan menentukan produk yang sesuai untuk memulai berwirausaha.

c. Pelatihan membuat business plan

d. Pelatihan menyusun laporan keuangan yang umum digunakan dalam usaha seperti : Neraca, Rugi laba, dan Arus kas.

e. Memberikan pelatihan penyusunan Rancangan Anggaran Belanja (RAB) produksi serta penghitungan break event point (BEP), ROI, PBP.

f. Pelatihan publick speaking. Dengan metode publick speaking melatih mereka untuk berani berbicara di depan umum supaya kelak ketika memasarkan produk akan lebih trampil cerdas kreatif dan berani.

g. Pelatihan budaya kerja, motivasi, soft skill, dan lain-lain.

h. Pelatihan membuat produk Usaha Mikro Kecil Menengah (UMKM) berupa produk bahan mentah menjadi produk cepat saji yaitu sejenis makanan Burger.

Target pelatihan dan pembekalan tersebut diatas secara tidak langsung bisa menjadi modal bagi para santri remaja putus sekolah pondok pesantren al Robbani. Meskipun santri di pondok pesantren tidak mendapatkan ilmu seperti yang diajar di sekolah umum lainnya maka mereka bisa belajar berdasarkan metode pembelajaran dan pelatihan kewirausahaan.

\section{SIMPULAN DAN SARAN}

\section{Simpulan}

Penelitian dan pengkajian motivasi pengembangan dan pematangan karir di pondok pesantren al Rabbani adalah memberikan model penyuluhan, praktek kewirausahaan dengan metode belajar ilmu-ilmu kewirausahaan. Materi yang diberikan seperti pemahaman karir; pembuatan business plan; pelatihan penyusunan RAB produksi serta menghitung BEP, ROI PBP; pelatihan budaya kerja, motivasi, soft skill dan lain-lain. Tidak hanya melalui metode pembelajarran dan pelatihan ilmu dasar kewirausahaan tersebut diatas, namun pada penelitian ini tim peneliti membekali dengan praktek pembuatan usaha mikro kecil menengah (UMKM) yaitu salah satu produk makanan cepat saji Burger. Penyuluhan dan pembekalan ini mampu membimbing para santri menjadi alumni pesantren memiliki karir mandiri dalam berwirusaha kreatif, dan inovatif.

\section{Saran}

Kegiatan kewirausahaan dapat dijadikan sebagai sarana ibadah, hal inilah yang memotivasi pondok pesantren al Rabbani untuk membuat wadah enterpenurship agar para santri lulusan pondok pesantren al Robbani bisa mendapatkan karir kewirausahaan. Penerapan kewirausahaan sebagai sarana ibadah maka sebaiknya pondok pesantren al Rabbani dapat melakukan kegiatan kewirausahaan serta membuat aturan bermuamalah dengan baik menjaga sikap yang baik kepada pelanggan memiliki motto bahwa rahasia dalam kegiatan kewirausahaan adalah jujur dan adil.

\section{DAFTAR RUJUKAN}

Abdillah, Ali M. Pemberdayaan wakaf uang untuk program entrepreneur bagi remaja putus sekolah di Pesantren al Rabbani. Jurnal al Awqaf (Jurnal Wakaf dan Ekonomi Islam) BWI, edisi Juli.

Hasanah, Uswatun, 2013. Wakaf dan pondok modern Darussalam Gontor. Jurnal al Awqaf (Jurnal Wakaf dan Ekonomi Islam) BWI, edisi Januari 2013.

Koentjaraningrat, Metode-metode Penelitian Masyarakat, Jakarta: Gramedia, cet. XIV. Tt.

Kumpulan Makalah Seminar Internasional Konseling Malindo 2 dan Kongres Ii Ikatan Konselor Indonesia ( Iki-Divisi Abkin ) November 2012

Modul Kewirausahaan. 2012. Unindra

Saiman, Leonardus. 2009. Kewirausahaan: Teori, Praktik dan kasus-kasus. Jakarta : Salemba Empat.

Soeradji, tt. Bimbingan Konseling Karir I, Jakarta : Universitas Indraprasta PGRI 
Sugiono. 2008. Metode Penelitian Pendidikan: Pendekatan Kuantitatif, Kualitatif, dan $R$ $\& D$, Bandung: Alfabeta.

Sriyono, Heru dan Suparman Ibrahim Abdullah. 2012. Bimbingan dan Konseling Belajar bagi siswa di sekolah. Jakarta : Raja Grafindo Persada.

Sumaryati, Theresia, Efektifitas Layanan Bimbingan dan Konseling dalam Menumbuhkan Minat Kewirausahaan Siswa Sekolah Menengah Kejuruan (SMK)
Tadika Pertiwi Cinere, Depok. Skripsi Unindra : Jakarta : 2015

Sunarto, T. (Bahan Kuliah Bimbingan Karir II, Universitas Indraprasta PGRI, tt)

Zimmere, Thomas W., Kewirausahaan dan Manajemen Usaha Kecil; et.all, Jakarta :Salemba Empat, Jakarta

http://www.cnnindonesia.com

http:bps.go.id 